\title{
Comparative characterization of $\mathrm{Cu}-\mathrm{Ni}$ substrates for coated conductors
}

Tian, H.; Suo, H.L.; Wulff, Anders Christian; Grivel, Jean-Claude; Mishin, Oleg; Juul Jensen, Dorte

Published in:

Journal of Alloys and Compounds

Link to article, DOI:

10.1016/j.jallcom.2014.02.114

Publication date:

2014

Document Version

Early version, also known as pre-print

Link back to DTU Orbit

Citation (APA):

Tian, H., Suo, H. L., Wulff, A. C., Grivel, J-C., Mishin, O., \& Juul Jensen, D. (2014). Comparative

characterization of $\mathrm{Cu}-\mathrm{Ni}$ substrates for coated conductors. Journal of Alloys and Compounds, 601, 9-13. https://doi.org/10.1016/j.jallcom.2014.02.114

\section{General rights}

Copyright and moral rights for the publications made accessible in the public portal are retained by the authors and/or other copyright owners and it is a condition of accessing publications that users recognise and abide by the legal requirements associated with these rights.

- Users may download and print one copy of any publication from the public portal for the purpose of private study or research.

- You may not further distribute the material or use it for any profit-making activity or commercial gain

- You may freely distribute the URL identifying the publication in the public portal 


\title{
Comparative characterization of $\mathrm{Cu}-\mathrm{Ni}$ substrates for coated conductors
}

\author{
H. Tian ${ }^{1}$, H.L. Suo ${ }^{11}$, A.C. Wulff ${ }^{2}$, J.-C. Grivel ${ }^{2}$, O.V. Mishin ${ }^{3}$, D. Juul Jensen ${ }^{3}$ \\ ${ }^{1}$ College of Materials Science and Engineering, Beijing University of Technology, 100124 \\ Beijing, China \\ ${ }^{2}$ Department of Energy Conversion and Storage, Technical University of Denmark, 4000 \\ Roskilde, Denmark \\ ${ }^{3}$ Danish-Chinese Center for Nanometals, Section for Materials Science and Advanced \\ Characterization, Department of Wind Energy, Technical University of Denmark, Risø Campus, \\ 4000 Roskilde, Denmark
}

\begin{abstract}
Three $\mathrm{Cu}_{100-x} \mathrm{Ni}_{x}$ alloys, with $x=23,33$ and 45 at.\%Ni, have been evaluated for use as substrates for coated conductors on the basis of measurements of their microstructure, crystallographic texture and hardness. It is found that high-temperature annealing after heavy rolling generates strong cube textures in each investigated alloy. For all of these alloys an increase in the annealing temperature from $800{ }^{\circ} \mathrm{C}$ to $1000{ }^{\circ} \mathrm{C}$ strengthens the cube texture and reduces the fraction of high angle grain boundaries. In the $\mathrm{Cu}-23$ at.\%Ni and $\mathrm{Cu}-33$ at.\%Ni alloys annealed at $1000{ }^{\circ} \mathrm{C}$ for $1 \mathrm{~h}$, the fraction of the cube texture approaches $100 \%$ and the fraction of high angle boundaries is less than $4 \%$. These two alloys are however very soft in the annealed condition. The cube texture in the $\mathrm{Cu}-45$ at.\%Ni substrate is slightly weaker than in the two other alloys, but this substrate
\end{abstract}

\footnotetext{
${ }^{1}$ Corresponding author: Tel. +86 10 67392947, E-mail: honglisuo@bjut.edu.cn
} 
is considerably harder, which makes it better suited for large scale production of superconducting tapes.

Keywords: Cu-Ni alloys; RABiTS; Cube texture; EBSD

\section{Introduction}

$\mathrm{Cu}-\mathrm{Ni}$ alloys with low Curie temperatures [1-6] are considered to be possible alternatives to $\mathrm{Ni}-5 \mathrm{at} . \% \mathrm{~W}$ and other Ni-based alloys [7-12] for use in the manufacture of $\mathrm{YBa}_{2} \mathrm{Cu}_{3} \mathrm{O}_{7}$ coated conductors, as it is expected that the use of such $\mathrm{Cu}-\mathrm{Ni}$ substrates, which are non-ferromagnetic at operating temperatures, will reduce energy losses in alternating current applications. Furthermore, since copper is significantly cheaper than nickel, the use of $\mathrm{Cu}-\mathrm{Ni}$ substrates in coated conductors may also reduce cost.

To enable high critical current densities in a superconducting layer, the frequency of high angle boundaries (HABs) in the substrate should be small, which can be achieved via a so-called rolling assisted biaxially textured substrates (RABiTS) process [7,13], utilizing heavy rolling and high temperature annealing. In face centered cubic (fcc) materials, recrystallization after heavy rolling typically results in a strong $\{001\}\langle 100\rangle$ cube texture which further strengthens during grain growth. Since growing grains of similar $\{001\}\langle 100\rangle$ orientations frequently form low angle boundaries (LABs), the process of grain growth in the presence of a strong cube texture can effectively reduce the fraction of HABs in the final microstructure $[5,14]$.

In several publications [1-6], it has been shown that a very strong cube texture can be obtained in $\mathrm{Cu}-\mathrm{Ni}$ substrates, however the influence of the chemical composition 
on the microstructure evolution during processing of such substrates has not been evaluated in these previous investigations. To enable a systematic comparative study, the evolution of microstructural parameters and texture in three different $\mathrm{Cu}-\mathrm{Ni}$ substrates is thoroughly characterized in the present work using the electron backscatter diffraction (EBSD) technique. The EBSD characterization of the annealed substrates is complemented by measurements of their hardness.

\section{Experimental}

$\mathrm{Cu}-23$ at.\%Ni, $\mathrm{Cu}-33$ at.\%Ni and $\mathrm{Cu}-45$ at.\%Ni alloys (in the following termed $\mathrm{Cu}-23 \mathrm{Ni}, \mathrm{Cu}-33 \mathrm{Ni}$ and $\mathrm{Cu}-45 \mathrm{Ni}$, respectively) were prepared in a high-frequency induction furnace using high-purity (99.95 wt.\%) $\mathrm{Cu}$ and $\mathrm{Ni}$. The ingots were heated to $1000{ }^{\circ} \mathrm{C}$ and hot deformed to produce bars, which were $\sim 10 \mathrm{~mm}$ thick and $15 \mathrm{~mm}$ wide. The hot-deformed bars were cooled in air, followed by surface grinding. The bars were then cold rolled applying 5\% reduction per pass to a final thickness of $70 \mu \mathrm{m}$. The total thickness reduction by cold rolling for each sample was $~ 99 \%$. The cold-rolled samples were annealed in a sealed quartz tube with inlet and outlet channels to allow the use of flowing $\mathrm{Ar}-5 \% \mathrm{H}_{2}$ gas. In these annealing experiments, the quartz tube containing the specimens was inserted into a preheated furnace. The heating-up time to reach the target temperature (either $800{ }^{\circ} \mathrm{C}, 900^{\circ} \mathrm{C}$ or $1000{ }^{\circ} \mathrm{C}$ ) for the specimens was measured to be 8-12 min. Following the heating-up period, most specimens were held in the furnace for $1 \mathrm{~h}$. The actual temperature during this $1 \mathrm{~h}$ exposure could slightly deviate from the target temperature. For example, for a target temperature of $800^{\circ} \mathrm{C}$, the temperature steadily increased to $814{ }^{\circ} \mathrm{C}$ over the $1 \mathrm{~h}$ anneal duration, as measured using a thermocouple. 
Such deviations are considered to be minor, and the target temperature is therefore given as the annealing temperature in the present work. In addition, a series of samples was prepared by heating up to $800{ }^{\circ} \mathrm{C}$ and annealing for different periods of time.

After annealing the quartz tube was retracted from the furnace, with the gas still flowing inside the tube, and tilted to allow the specimen to slide into a cold zone of the tube. This enabled quick cooling of the specimen inside the tube. According to our measurements, the specimen temperature dropped to below $100{ }^{\circ} \mathrm{C}$ within only 1 min.

Microstructures and textures of the samples were examined in a Zeiss Supra 35 field emission gun scanning electron microscope equipped with a Channel 5 EBSD system. A step size of $20 \mathrm{~nm}$ was used for collecting EBSD data in the cold-rolled samples. For partially recrystallized conditions, the EBSD step size was chosen to be either $100 \mathrm{~nm}$ or $200 \mathrm{~nm}$. To measure microstructural parameters in the recrystallized samples, step sizes of $1 \mu \mathrm{m}$ to $2.5 \mu \mathrm{m}$ were applied for collecting EBSD maps from areas of at least $500 \times 500 \mu \mathrm{m}^{2}$. Texture in the recrystallized samples was measured from areas of $\sim 2 \mathrm{~mm}^{2}$ investigated with a step size of $4 \mu \mathrm{m}$. LABs and HABs were defined as boundaries with misorientations of $2-15^{\circ}$ and $>15^{\circ}$, respectively. In addition, the frequency of misorientations $>10^{\circ}$ was also calculated for the annealed substrates because grain boundaries with such misorientations can significantly decrease the critical current density of an epitaxially grown $\mathrm{YBa}_{2} \mathrm{Cu}_{3} \mathrm{O}_{7}$ layer [15]. All values representing the average grain size and boundary spacings along either the normal direction $\left(d_{\mathrm{ND}}\right)$, the transverse direction $\left(d_{\mathrm{TD}}\right)$, or the rolling direction $\left(d_{\mathrm{RD}}\right)$ were calculated in this work considering annealing twins to be grains. Following previous work on copper [16,17], $\Sigma 3$ boundaries were defined by applying a maximum deviation of $3^{\circ}$ from the ideal $60^{\circ}<111>$ misorientation. Vickers hardness measurements were performed using a load 
of $200 \mathrm{~g}$ with a dwell time of $15 \mathrm{~s}$, averaging over at least 9 individual measurements for each condition.

\section{Results}

\subsection{Samples after deformation}

As shown in Fig.1, the samples obtained by hot deformation are fully recrystallized with a large frequency of annealing twins. The average grain size $D$ calculated from the Figure 1 for all crystallites including the twins is $16 \mu \mathrm{m}, 12 \mu \mathrm{m}$ and $9 \mu \mathrm{m}$ for samples $\mathrm{Cu}-23 \mathrm{Ni}, \mathrm{Cu}-33 \mathrm{Ni}$ and $\mathrm{Cu}-45 \mathrm{Ni}$, respectively (see Table 1 ). The fraction of HABs $\left(f_{\mathrm{HAB}}\right)$ in these samples is similar, 97-98\% (see Table 1). Furthermore, the hot-deformed samples are characterized by very weak crystallographic textures.

Heavy cold rolling results in strong rolling textures [5] and in a characteristic deformed microstructure comprising lamellar boundaries [18,19] almost parallel to the rolling plane and shear bands aligned at $22-36^{\circ}$ to the $\mathrm{RD}$ (Fig.2). In each sample, $f_{\mathrm{HAB}}$ is $\sim 70 \%$, whereas $d_{\mathrm{ND}}$ varies from $77 \mathrm{~nm}$ for $\mathrm{Cu}-23 \mathrm{Ni}$ to $67 \mathrm{~nm}$ for $\mathrm{Cu}-45 \mathrm{Ni}$ (see Table 1 ).

\subsection{Annealed samples}

EBSD maps from the samples annealed at different temperatures for $1 \mathrm{~h}$ are shown in Fig.3, where it is seen that the area fraction of cube-oriented grains is sensitive both to the alloy composition and to the annealing temperature. Whereas there are significant frequencies of orientations with large deviations from the ideal cube orientation in the samples annealed at $800{ }^{\circ} \mathrm{C}$, such grains are very rare after annealing at $1000{ }^{\circ} \mathrm{C}$ (see Fig.3). In the $\mathrm{Cu}-23 \mathrm{Ni}$ and $\mathrm{Cu}-33 \mathrm{Ni}$ samples, the fraction of orientations 
within $10^{\circ}$ of the ideal cube orientation ( $\left.f_{\text {Cube }}\right)$ increases from $95-96 \%$ after annealing at $800{ }^{\circ} \mathrm{C}$ to almost $100 \%$ after annealing at $1000{ }^{\circ} \mathrm{C}$ (Fig.4). The cube texture is weaker in the $\mathrm{Cu}-45 \mathrm{Ni}$ sample, where $f_{\text {Cube }}$ is $73 \%$ and $92 \%$ after annealing at $800{ }^{\circ} \mathrm{C}$ and $900{ }^{\circ} \mathrm{C}$, respectively. However, after annealing at $1000^{\circ} \mathrm{C}$ the fraction of the cube texture becomes very high, $f_{\text {Cube }}=97 \%$, even in this Ni-rich material (see Fig.4).

For the majority of the annealing conditions, the HAB fraction decreases both with decreasing Ni content and with increasing annealing temperature (see Table 1). The lowest fraction of HABs (less than 1\%) is obtained in the $\mathrm{Cu}-23 \mathrm{Ni}$ sample annealed at $1000{ }^{\circ} \mathrm{C}$ for $1 \mathrm{~h}$ (see Fig.3). The fraction of boundary misorientations greater than $10^{\circ}$ after annealing at this temperature is $21 \%$ in the $\mathrm{Cu}-45 \mathrm{Ni}$ sample and only $2-5 \%$ in the other samples (Fig.5).

The mean boundary spacing calculated as $d_{\mathrm{m}}=\left(d_{\mathrm{TD}}+d_{\mathrm{RD}}\right) / 2$ generally decreases with increasing $\mathrm{Ni}$ content, though the difference in $d_{\mathrm{m}}$ between the $\mathrm{Cu}-33 \mathrm{Ni}$ and $\mathrm{Cu}-45 \mathrm{Ni}$ samples annealed at $800{ }^{\circ} \mathrm{C}$ and $900{ }^{\circ} \mathrm{C}$ is not significant (see Fig.6). For each alloy, an increase in the annealing temperature results in a coarser average grain size (Fig.6), which reduces the hardness (see Fig.7). The Vickers hardness measured after annealing at $1000^{\circ} \mathrm{C}$ for $1 \mathrm{~h}$ is only $56 \mathrm{HV}$ in the $\mathrm{Cu}-23 \mathrm{Ni}$ sample, but increases with increasing Ni content, reaching $77 \mathrm{HV}$ in the $\mathrm{Cu}-45 \mathrm{Ni}$ sample (Fig.7).

\section{Discussion}

The three $\mathrm{Cu}-\mathrm{Ni}$ alloys investigated in the present work are characterized by significant differences in the microstructure already in the hot-deformed condition (Fig.1 and Table 1). Since no deformation structure is observed in these hot-deformed samples, it is apparent that the temperature of the bars immediately after deformation was 
sufficiently high to result in complete static recrystallization. The fact that the average recrystallized grain size in the hot-deformed $\mathrm{Cu}-23 \mathrm{Ni}$ sample was larger than the grain size in the two other samples suggests that in $\mathrm{Cu}-23 \mathrm{Ni}$ there were fewer recrystallization nuclei compared to the samples with the higher amounts of $\mathrm{Ni}$.

Similar to the difference in the grain size after hot deformation (Fig.2), the largest spacing between lamellar boundaries is obtained for the $\mathrm{Cu}-23 \mathrm{Ni}$ sample, whilst the smallest spacing is recorded for the $\mathrm{Cu}-45 \mathrm{Ni}$ sample (see Table 1). In our previous study of $\mathrm{Cu}-45 \mathrm{Ni}$ [5], it has been shown that annealing after heavy rolling first leads to recovery, which involves a coarsening of the lamellar microstructure [20,21]. This initial stage is followed by discontinuous recrystallization and, finally, by grain growth. To identify each of these stages in the samples studied in the present work, hardness measurements were performed after different periods of time in the furnace preheated to enable annealing at $\sim 800{ }^{\circ} \mathrm{C}$. The results of these measurements are shown in Fig.8. It is seen that after only 1 minute, when the actual temperature reaches $\sim 550{ }^{\circ} \mathrm{C}$, the hardness decreases by approximately $10-20 \%$. This initial softening is considered to be due to recovery leading both to reduced dislocation density and to lamellar coarsening. Further annealing up to 5 minutes, where the temperature is still below $800{ }^{\circ} \mathrm{C}$ (see Fig.8), leads to a pronounced drop in hardness, indicating discontinuous recrystallization. It is therefore clear that recrystallization in each alloy occurs during the heating-up period. Annealing beyond 5 minutes results in a slow reduction in hardness, which suggests that at this stage the microstructure evolves predominantly by growth of recrystallized grains. Comparing the three curves in Fig.8, it is apparent that the $\mathrm{Cu}-23 \mathrm{Ni}$ sample softens more rapidly than the other samples. 
To observe the microstructure in partially recrystallized conditions, we investigated the $\mathrm{Cu}-23 \mathrm{Ni}$ and $\mathrm{Cu}-45 \mathrm{Ni}$ samples after $2 \mathrm{~min}$ in the furnace. As is evident from EBSD maps in Fig.9, there is a very large difference in the extent of recrystallization in these two samples. In the $\mathrm{Cu}-23 \mathrm{Ni}$ sample, recrystallized grains are fairly large (see Fig.9(a)), with an equivalent circular diameter (ECD) of up to $40-60 \mu \mathrm{m}$, and the area fraction of the recrystallized microstructure is approximately $65 \%$. In contrast, only a few small recrystallized grains $(\mathrm{ECD}<5 \mu \mathrm{m})$ are observed in the $\mathrm{Cu}-45 \mathrm{Ni}$ sample, in which the lamellar microstructure is largely preserved (Fig.9(b)). It is therefore obvious that recrystallization in the low-Ni sample proceeds faster and results in larger grains than in the samples with the higher amounts of $\mathrm{Ni}$. In general, these differences can be both due to the differences in the deformed microstructure of the alloys and due to differences in the solute drag [22,23]. As the latter controls the boundary migration, the large differences in the chemical composition could affect either or both of the processes involving boundary migration before and during recrystallization, namely initial coarsening of the lamellar structures, and nucleation and growth of recrystallization nuclei.

Analysis of orientations in the partially recrystallized $\mathrm{Cu}-23 \mathrm{Ni}$ sample indicates that the largest grains have orientations deviated by less than $10^{\circ}$ from the ideal $\{001\}\langle 100\rangle$ orientation (see Fig.9(a)). The larger average size of cube-oriented grains as compared to grains of other orientations is in agreement with previous observations in other fcc materials $[5,24,25]$. Such large $\{001\}\langle 100\rangle$ grains gain growth advantage during further annealing, consuming grains of other orientations. During grain growth cubeoriented grains encounter one another, which leads to the formation of new LABs and reduces the fraction of boundaries with large misorientations (including those $>10^{\circ}$, see 
Fig.5). The comparatively low fraction of the cube texture in the $\mathrm{Cu}-45 \mathrm{Ni}$ sample annealed at $800{ }^{\circ} \mathrm{C}$ (Fig.4) suggests that for this alloy the boundary mobility at $800{ }^{\circ} \mathrm{C}$ was not high enough to effectively eliminate non-cube crystallites present in the microstructure. However, when the temperature increases to $900{ }^{\circ} \mathrm{C}$ and $1000{ }^{\circ} \mathrm{C}$ (which increases the boundary mobility), cube-oriented grains are able to grow very rapidly even in this Ni-rich alloy, and the difference in the fraction of the cube texture between the different alloys becomes smaller.

Considering that the fraction of boundaries with misorientations $>10^{\circ}$ is lowest in the $\mathrm{Cu}-23 \mathrm{Ni}$ sample annealed at $1000^{\circ} \mathrm{C}$ for $1 \mathrm{~h}$, it can be concluded that its microstructure is better suited in ensuring a high critical current density than the microstructure of the other two alloys. This alloy is, however, rather soft (see Fig.7), which can cause handling issues during manufacturing of long coated conductor tapes. Taking into account that the hardness of the $\mathrm{Cu}-45 \mathrm{Ni}$ sample is higher than that of both $\mathrm{Cu}-23 \mathrm{Ni}$ and $\mathrm{Cu}-33 \mathrm{Ni}$, and that its microstructural characteristics after annealing at $1000{ }^{\circ} \mathrm{C}$ for $1 \mathrm{~h}$ are sufficiently good even in comparison with the commonly used $\mathrm{Ni}-5$ at.\%W substrates [8], the $\mathrm{Cu}-45$ at.\%Ni alloy is considered to be a better candidate for potential use as a substrate material for coated conductors than the other two $\mathrm{Cu}-\mathrm{Ni}$ alloys studied in the present work.

\section{Summary}

The evolution of the microstructure and crystallographic texture during deformation and annealing of $\mathrm{Cu}-23$ at.\%Ni, $\mathrm{Cu}-33$ at.\%Ni and $\mathrm{Cu}-45$ at.\%Ni alloys has been investigated in this work aiming at developing non-ferromagnetic substrates for coated conductors. After each processing step the boundary spacing is found to be consistently 
greater in the alloy with the lowest $\mathrm{Ni}$ content. For each material, the cube texture strengthens and the frequency of boundaries with large misorientations decreases with increasing annealing temperature. After annealing at $1000^{\circ} \mathrm{C}$ for $1 \mathrm{~h}$ the fraction of the cube texture in the $\mathrm{Cu}-23$ at. $\% \mathrm{Ni}$ alloy is almost $100 \%$ and the fraction of boundary misorientations $>10^{\circ}$ is only $2 \%$. Although this microstructure is better suited in ensuring a high critical current density than the annealed microstructure of the other samples, the $\mathrm{Cu}-23$ at.\%Ni alloy annealed at $1000{ }^{\circ} \mathrm{C}$ is very soft, and therefore is not considered to be a good substrate material. In contrast, $\mathrm{Cu}-45$ at.\%Ni is characterized by the highest hardness, combined with sufficiently good microstructure and texture after annealing at $1000{ }^{\circ} \mathrm{C}$ for $1 \mathrm{~h}$. Thus, the $\mathrm{Cu}-45$ at. $\% \mathrm{Ni}$ alloy annealed at $1000{ }^{\circ} \mathrm{C}$ for $1 \mathrm{~h}$ appears to be more suitable as a substrate material for coated conductors than the two other $\mathrm{Cu}-\mathrm{Ni}$ alloys.

\section{Acknowledgements}

The authors gratefully acknowledge the support from the Danish National Research Foundation (Grant No. DNRF86-5) and the National Natural Science Foundation of China (Grant No. 51261130091) to the Danish-Chinese Center for Nanometals, within which part of the present work was performed. H.T. and H.L.S. are also grateful to the National Natural Science Foundation of China (51171002), Beijing Municipal Natural Science Foundation (2132011 and KZ201310005003), the Specialized Research Fund for the Doctoral Program of Higher Education (20121103110012) and the Danish Agency for Science, Technology and Innovation (Grant No.09-065234) for supporting this research work. 


\section{References}

[1] K. Shi, Y. Zhou, J. Meng, J. Yang, G.Y. Hu, H.W. Gu, G.S. Yuan, Phys. C 386 (2003) 353-357.

[2] J.L. Soubeyroux, C.E. Bruzek, A. Girard, J.L. Jorda, IEEE Trans. Appl. Supercond. 15 (2005) 2687-2690.

[3] A. Girard, C.E. Bruzek, J.L. Jorda, L. Ortega, J.L. Soubeyroux, J. Phys: Conf. Ser. 43 (2006) 341-344.

[4] A. Vannozzi, G. Celentano, A.A. Angrisani, A. Augieri, L. Ciontea, I. Colantoni, V. Galluzi, U. Gambardella, A Mancini, T Petrisor, A Rufoloni, G. Thalmaier, J. Phys: Conf. Ser. 97 (2008) 1-6.

[5] H. Tian, H.L. Suo, O.V. Mishin, Y.B. Zhang, D. Juul Jensen, J. Mater. Sci. 48 (2013) 4183-4190.

[6] H. Tian, H.L. Suo, Y. Zhao, O.V. Mishin, J.-C. Grivel, Mater Let. 108 (2013) 142144.

[7] A. Goyal, M. Parans Paranthaman, U. Schoop, MRS Bulletin 29 (2004) 552-561.

[8] A.C. Wulff, O.V. Mishin, J.-C. Grivel J. Alloys Compd. 539 (2012) 161-167.

[9] M.M. Gao, H.L. Suo, J.-C. Grivel, Y. Zhao, P.K. Gao, M. Liu, L. Ma. IEEE Trans. Appl. Supercond. 21 (2011) 2969-2972.

[10] J. Eickemeyer, R. Hühne, A. Güth, C. Rodig, U. Gaitzsch, J. Freudenberger, L.

Schultz, B. Holzapfel. Supercond. Sci. Technol. 23 (2010) 1-6. 085012

[11] U. Gaitzsch, J. Eickemeyer, C. Rodig, J. Freudenberger, B. Holzapfel, L. Schultz. Scr. Mater. 62 (2010) 512-515.

[12] U. Gaitzsch, J. Hänisch, R. Hühne, C. Rodig, J. Freudenberger, B. Holzapfel, L. Schultz. Supercond. Sci. Technol. 26 (2013) 1-6. 085024. 
[13] A. Goyal, D.P. Norton, J.D. Budai, M. Paranthaman, E.D. Specht, D.M. Kroeger, D.K. Christen, Q. He, B. Saffian, F.A. List, D.F. Lee, P.M. Martin, C.E. Klabunde, E. Hatfield, V.K. Sikka, Appl. Phys. Lett. 69 (1996) 1795-1797.

[14] O.V. Mishin, G. Gottstein, Mater. Sci. Eng. A 249 (1998) 71-78.

[15] J.H. Durrell, N.A. Rutter, Supercond. Sci. Technol. 22 (2009) 013001.

[16] O.V. Mishin, X. Huang, Mater. Sci. Forum 294-296 (1999) 401-404.

[17] O.V. Mishin, J. Mater. Sci. 33 (1998) 5137-5143.

[18] D.A. Hughes, N.Hansen, Acta Mater. 48 (2000) 2985-3004.

[19] D.A. Hughes, N. Hansen, Metal. Trans. A24 (1993) 2021-2037.

[20] T. Yu, N. Hansen, X. Huang, Proc R Soc A467 (2011) 3039-3065.

[21] O.V. Mishin, A. Godfrey, D. Juul Jensen, N. Hansen, Acta Mater. 61 (2013) 53545364.

[22] F.J. Humphreys and M. Hatterly, Recrystallization and Related Annealing Phenomena, 2nd ed., Elsevier Ltd., Oxford, 2004.

[23] M. Suehiro, Z.-K. Liu, J. Ågren, Metall. Mater. Trans. A, 29 (1998) 1029-1034.

[24] D. Juul Jensen, Acta Metall. Mater. 43 (1995) 4117-4129.

[25] X.L. Li, W. Liu, A. Godfrey, D. Juul Jensen, Q. Liu, Acta Mater. 55 (2007) 35313540. 
Table 1 Microstructural parameters determined using the EBSD technique.

\begin{tabular}{|c|c|c|c|c|c|c|c|c|c|c|}
\hline \multirow[t]{2}{*}{ Sample } & \multicolumn{2}{|c|}{$\begin{array}{c}\text { Hot- } \\
\text { deformed }\end{array}$} & \multicolumn{2}{|c|}{ Cold-rolled } & \multicolumn{2}{|c|}{$\begin{array}{c}800^{\circ} \mathrm{C} \text { for } \\
1 \mathrm{~h}\end{array}$} & \multicolumn{2}{|c|}{$\begin{array}{c}900^{\circ} \mathrm{C} \text { for } \\
1 \mathrm{~h}\end{array}$} & \multicolumn{2}{|c|}{$\begin{array}{c}1000^{\circ} \mathrm{C} \text { for } \\
1 \mathrm{~h}\end{array}$} \\
\hline & $\begin{array}{c}D \\
(\mu \mathrm{m})\end{array}$ & $\begin{array}{r}f_{\mathrm{HAB}} \\
(\%)\end{array}$ & $\begin{array}{l}d_{\mathrm{ND}} \\
(\mathrm{nm})\end{array}$ & $\begin{array}{c}f_{\mathrm{HAB}} \\
(\%)\end{array}$ & $\begin{array}{c}d_{\mathrm{m}} \\
(\mu \mathrm{m})\end{array}$ & $\begin{array}{l}f_{\mathrm{HAB}} \\
(\%)\end{array}$ & $\begin{array}{c}d_{\mathrm{m}} \\
(\mu \mathrm{m})\end{array}$ & $\begin{array}{r}f_{\mathrm{HAB}} \\
(\%)\end{array}$ & $\begin{array}{c}d_{\mathrm{m}} \\
(\mu \mathrm{m})\end{array}$ & $\begin{array}{l}f_{\mathrm{HAB}} \\
(\%)\end{array}$ \\
\hline $\mathrm{Cu}-23 \mathrm{Ni}$ & 16 & 97 & 77 & 70 & 27 & 17 & 32 & 12 & 37 & $<1$ \\
\hline $\mathrm{Cu}-33 \mathrm{Ni}$ & 12 & 98 & 75 & 71 & 17 & 25 & 25 & 9 & 34 & 3 \\
\hline $\mathrm{Cu}-45 \mathrm{Ni}$ & 9 & 97 & 67 & 71 & 16 & 52 & 24 & 21 & 31 & 12 \\
\hline
\end{tabular}




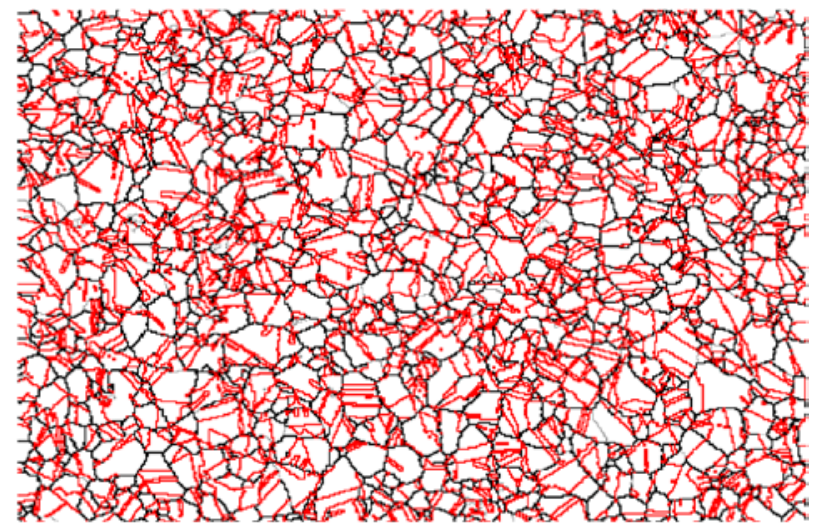

(a)

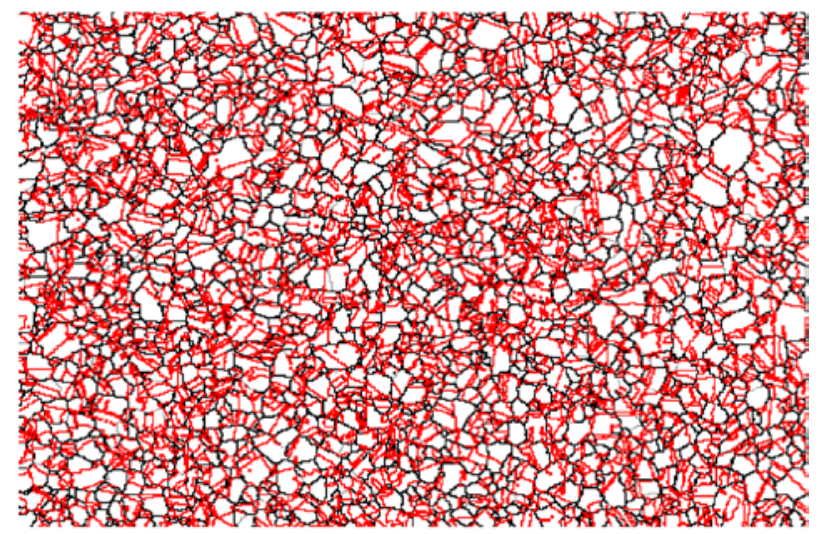

(b)

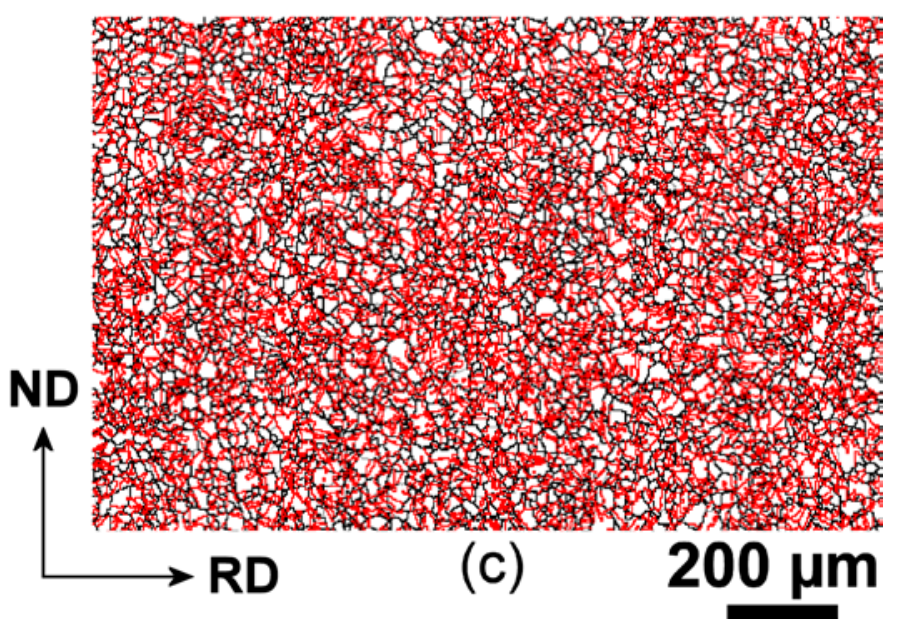

Fig.1. EBSD maps showing the microstructure in the hot-deformed samples: (a) $\mathrm{Cu}-23 \mathrm{Ni}$; (b) $\mathrm{Cu}-33 \mathrm{Ni}$, (c) $\mathrm{Cu}-45 \mathrm{Ni}$. LABs and HABs (other than $\Sigma 3$ ) are shown in gray and black, respectively. $\Sigma 3$ boundaries are shown in red. (For interpretation of the references to color, the reader is referred to the web version of this article.) 


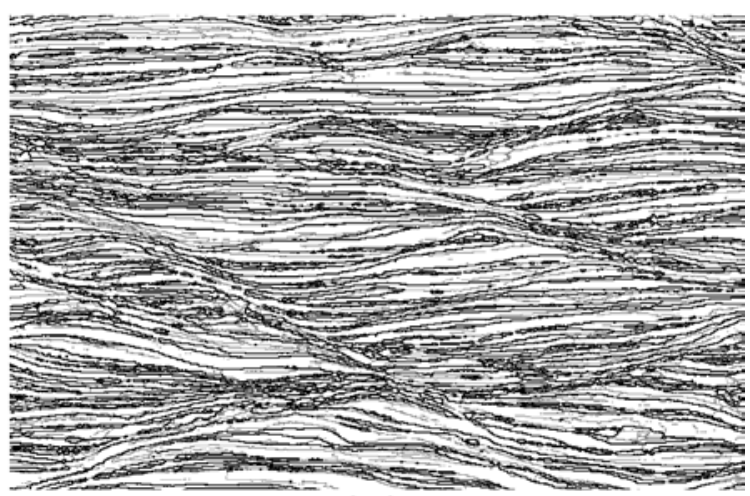

(a)

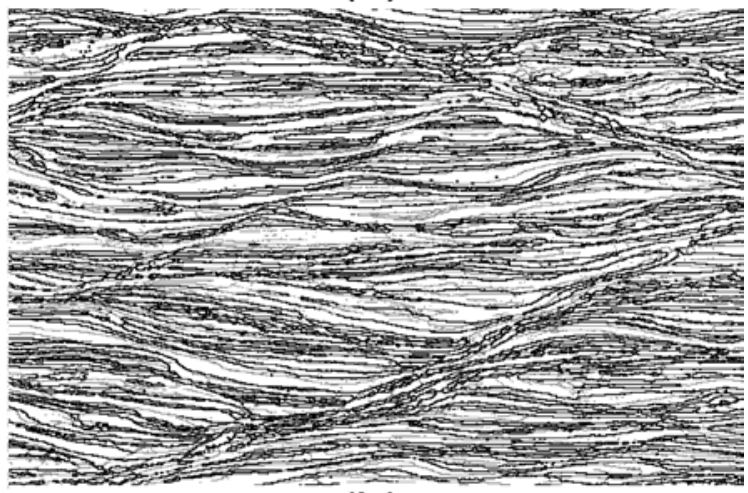

(b)

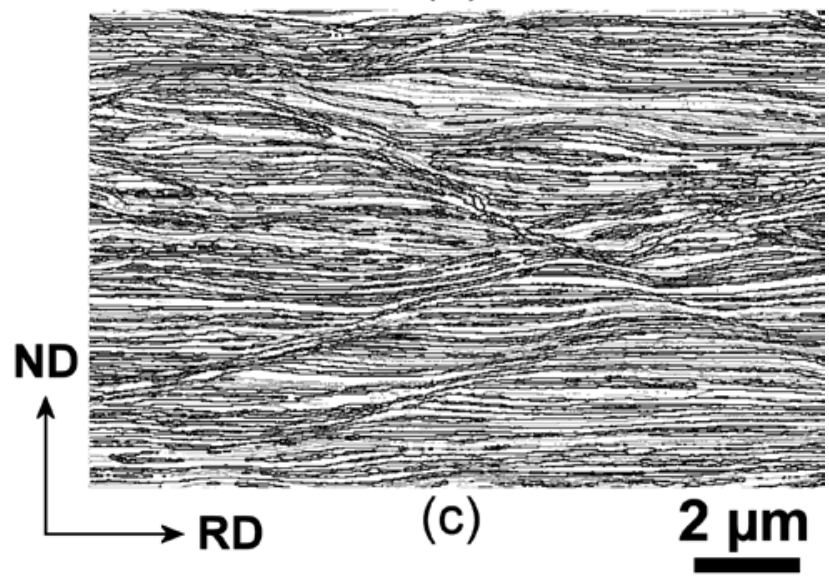

Fig.2. EBSD maps showing the microstructure in the longitudinal section of the coldrolled samples: (a) $\mathrm{Cu}-23 \mathrm{Ni}$; (b) $\mathrm{Cu}-33 \mathrm{Ni}$, (c) $\mathrm{Cu}-45 \mathrm{Ni}$. LABs and HABs (other than $\Sigma 3$ ) are shown in gray and black, respectively. $\Sigma 3$ boundaries are shown in red. (For interpretation of the references to color, the reader is referred to the web version of this article.) 


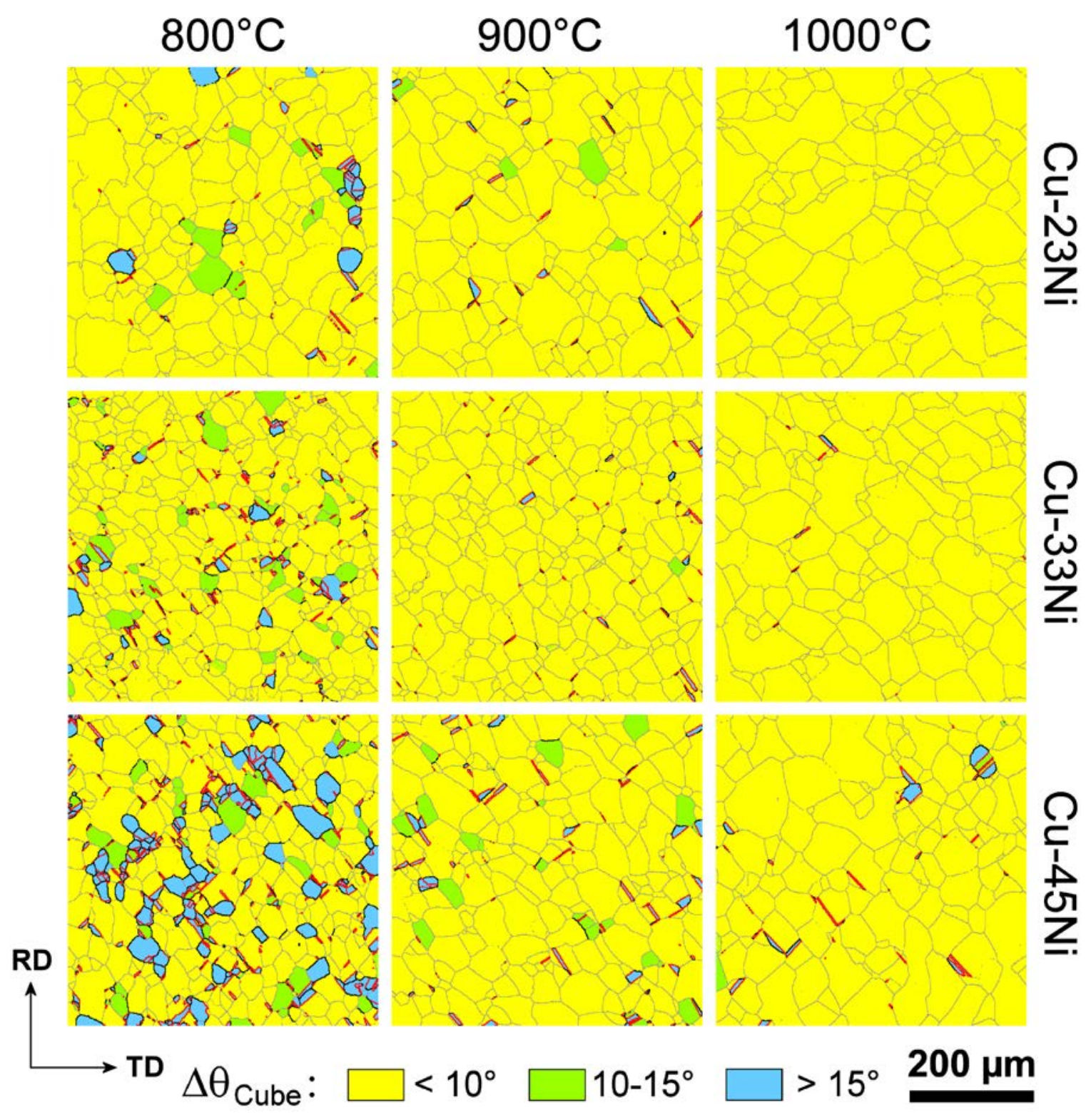

Fig.3. EBSD maps from the rolling plane showing microstructures after annealing at different temperatures for $1 \mathrm{~h}$. The color code for different deviations from the exact $\{001\}\langle 100\rangle$ orientation, $\Delta \theta_{\text {Cube }}$, is given in the legend. LABs and HABs (other than $\Sigma 3$ ) are shown in gray and black, respectively. $\Sigma 3$ boundaries are shown in red. (For interpretation of the references to color, the reader is referred to the web version of this article.) 


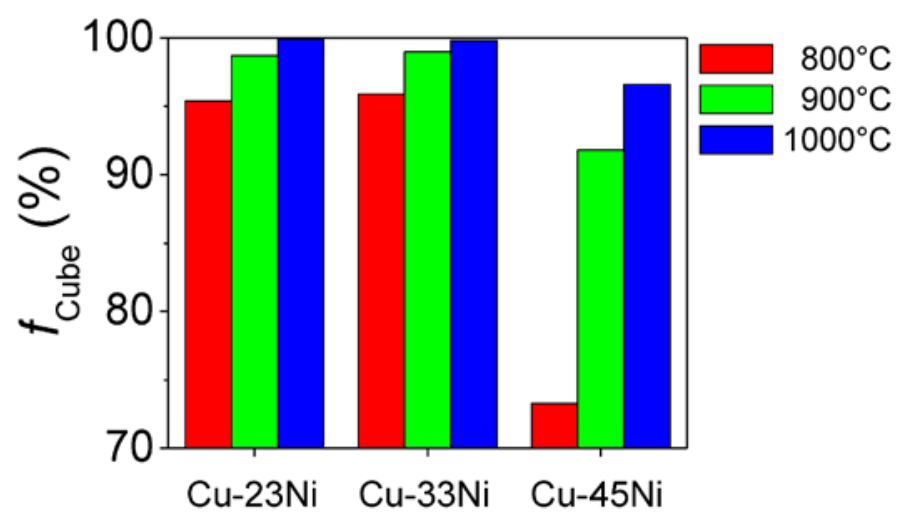

Fig.4. Fractions of the cube texture within $10^{\circ}$ from the ideal $\{001\}\langle 100\rangle$ orientation after annealing at different temperatures for $1 \mathrm{~h}$.

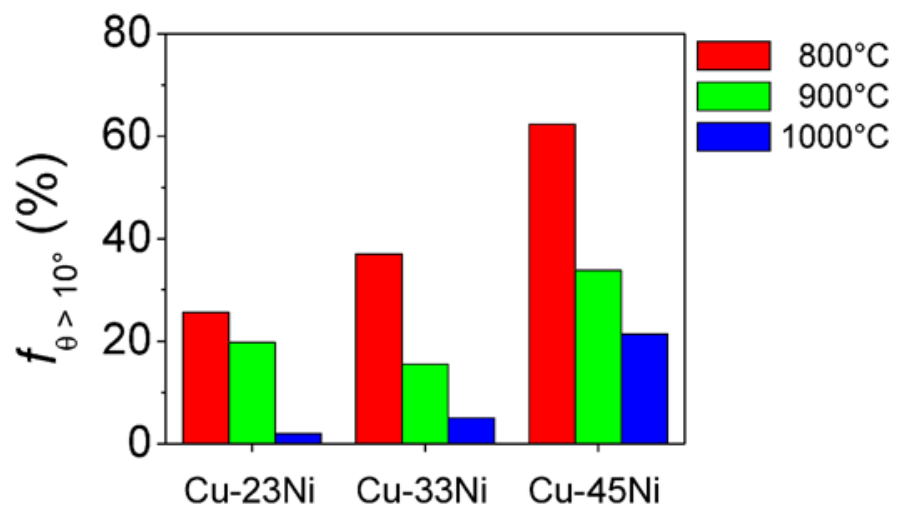

Fig.5. Fractions of boundary misorientations $>10^{\circ}$ after annealing at different temperatures for $1 \mathrm{~h}$.

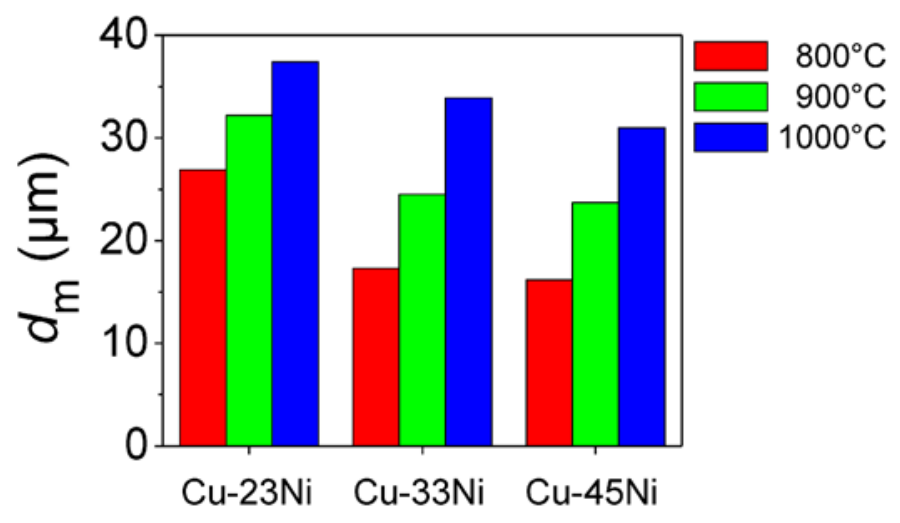

Fig.6. The average grain size measured in the rolling plane after annealing at different temperatures for $1 \mathrm{~h}$. 


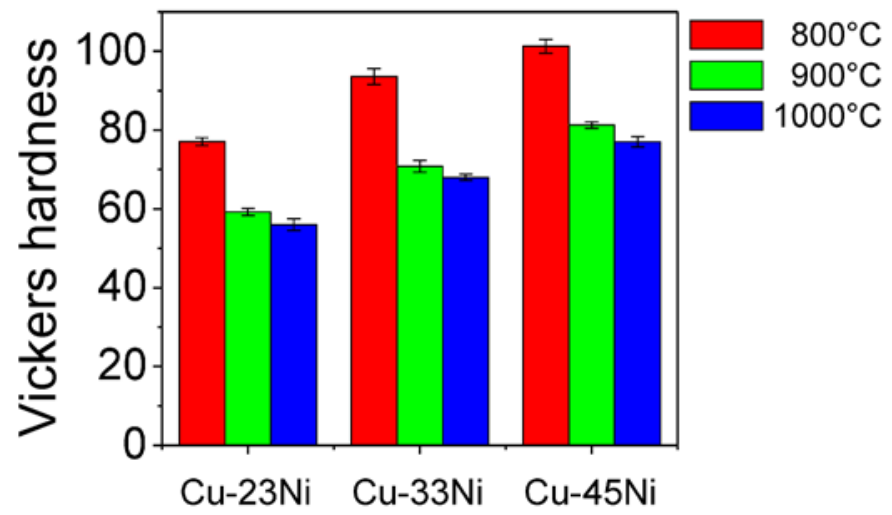

Fig.7. Vickers hardness after annealing at different temperatures for $1 \mathrm{~h}$. The error bars correspond to the standard deviation.

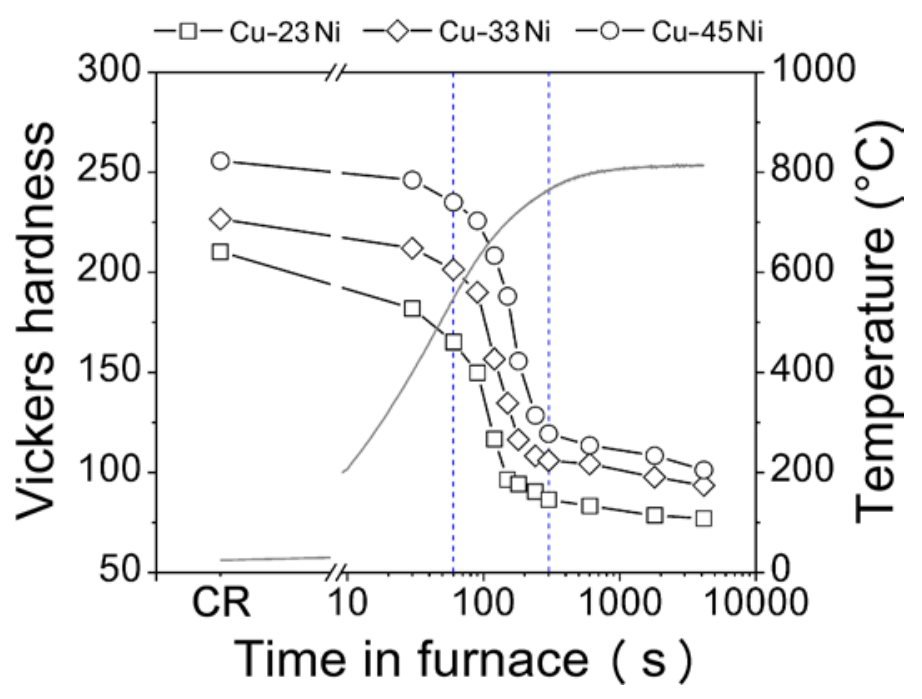

Fig.8. The evolution of the Vickers hardness after different periods of time in the furnace (black lines) for a target temperature of $800^{\circ} \mathrm{C}$, and an actual thermal profile (grey line) determined near the specimen location. "CR" corresponds to the cold-rolled condition. The dashed lines mark a period of time (between 1 minute and 5 minutes), during which a pronounced drop in hardness is observed. 


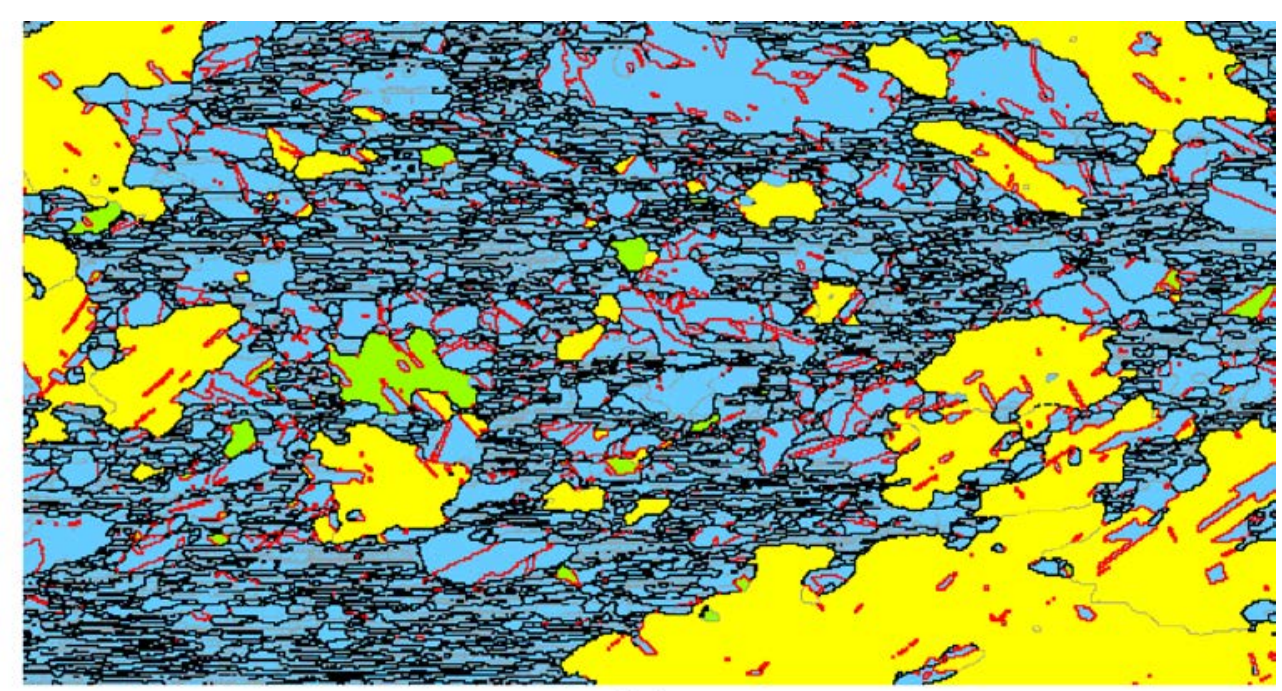

(a)

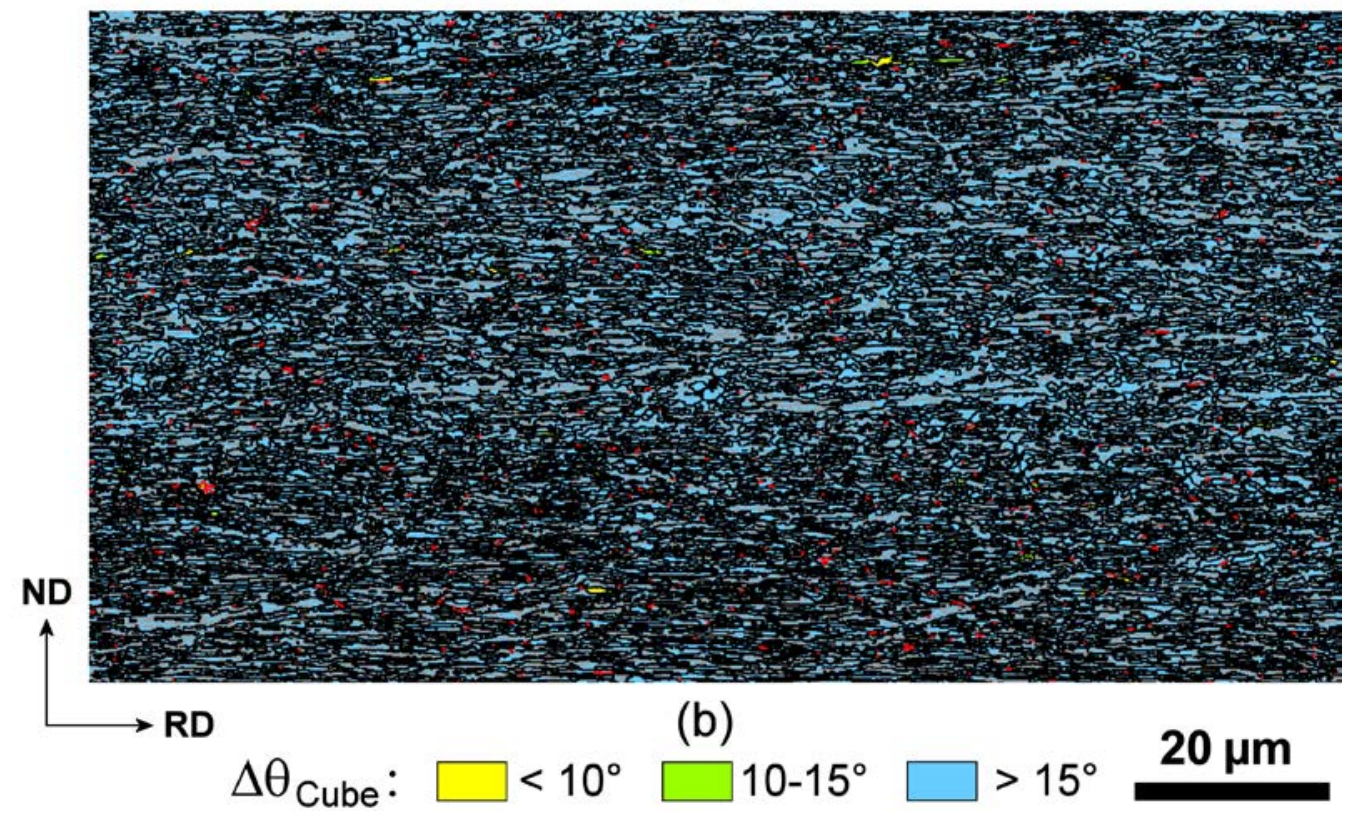

Fig.9. EBSD maps from the longitudinal section of the samples after 2 min in the furnace (when the temperature reached $670{ }^{\circ} \mathrm{C}$, see Fig.8): (a) $\mathrm{Cu}-23 \mathrm{Ni}$ and (b) $\mathrm{Cu}-45 \mathrm{Ni}$. The color code for different deviations from the exact $\{001\}\langle 100\rangle$ orientation, $\Delta \theta_{\text {Cube, }}$, is given in the legend. Black and thin gray lines show HABs (other than 53 ) and LABs, respectively. $\Sigma 3$ boundaries are shown in red. The scale bar is parallel to the RD. (For interpretation of the references to color, the reader is referred to the web version of this article.) 